\title{
Investigation of the Evangelism of Sport Team's Attitudes of the High School Students
}

\author{
Hüseyin Fatih Küçükibiş ${ }^{1}$, Zühal Yurtsızoğlu ${ }^{1}$ \\ ${ }^{1}$ The School of Physical Education and Sports, Sivas Cumhuriyet University, Sivas- Turkey \\ Correspondence: Hüseyin Fatih Küçükibiş, The School of Physical Education and Sports, Sivas Cumhuriyet University, \\ Sivas- Turkey.
}

Received: February 2, 2019

Accepted: March 15, 2019

Online Published: March 19, 2019

doi:10.11114/jets.v7i3S.4154

URL: https://doi.org/10.11114/jets.v7i3S.4154

\begin{abstract}
Developments in the sports industry have increased rivalry, professional sports clubs have moved towards economic activities in order to maintain their existence and have started to act like a business. Understanding the tendencies of the sports club fans, where the sports clubs interact intensively, will play a key role in the development of the sport. The aim of this study was to determine the sports team evangelism attitudes of high school students and to examine the evangelist behaviours. The research group consists of a total of 376 students in high school in Sivas. A descriptive qualitative survey model was used in the study. In order to determine the demographic characteristics of the participants, the eight-item personal information form, and the 12-item Sport Team Evangelism Scale which were developed by Dwyer, Greenhalgh and LeCrom (2015) and adapted to Turkish by Yüksekbilgili (2017) were used. Frequency, percentage, mean and standard deviation values were used for data analysis. Normality tests of the data were performed and Mann Whitney $\mathrm{U}$ test and Kruskal Wallis $\mathrm{H}$ test were used to compare the variables that did not show normal distribution. According to the findings, it was observed that sport team evangelism levels differed statistically according to the participants' gender, the number of teams they went to, the frequencies of going to matches, the way they followed the matches, and the way to go away. It is seen that the level of evangelism of the sports team of the participants is moderate. Clubs are advised to develop marketing and marketing strategies for products and services, taking into account the profile and evangelist tendencies of the fans.
\end{abstract}

Keywords: sports team, evangelism, high school student, attitude

\section{Introduction}

The globalization phenomenon that has affected all sectors economically caused great economic and structural changes in sports sector (especially football). The income and financial movements of the major football clubs in the countries have left many businesses behind. The goods and services within the sports industry are spread out over a wide range from construction to tourism, from food to sports, from sports products to gift items and entertainment.

In the sports industry that has grown and become a giant and global sector, sports clubs have evolved and transformed into giant economic enterprises. The football clubs have started to create their own brands, each club has turned into a large economic enterprise, and the goods and services they offered have turned into brands.

The club's supporters, on the other hand, have transformed into potential consumers for the club or the loyal customers who use the products and services the club offered; they have transformed into advertisers while using those products; they have become brand advocates who explain and impose those products to their environments and allow the club to become a brand; they have even transformed into the brand evangelists.

The economic value of clubs increases or decreases depending on the profitability, recognition, perceived quality of the club brand, the strength of the associations and the level of loyalty of consumers (Alkibay, 2005). Being loyal to a brand means not only buying the same brand regularly as the consumers, but also developing a strong and positive attitude towards the brand (Solomon, 2013). Faithful fans and consumers have identified themselves with their own team among alternative brands, and have started to consume the products and services of their team regularly to the extent of the severity of this identification. Even the fans, without any counterparts, have begun to advertise their team's products and have tended to impose their thoughts on those around them. 
Loyal consumers can develop a positive mouth-to-mouth communication (or brand support) about the brand they are affiliated with. They can also recommend this brand to others and may encourage new consumers to try it out. In addition, the loyal consumer protects his own brand from negative opinions or rumours (Amine, 1998). The loyal consumer enjoys talking with others about the brand, recommends the product to others, convinces them to buy and impose it on their immediate surroundings. Loyal consumers and fanatical supporters who are devoted to the products and services the clubs produce are extremely important for the football clubs (businesses), which are in a highly competitive environment where consumer needs, demands and expectations change constantly. Keeping a consumer whose expectations are satisfied with a product or service purchased is less costly and easier than getting new consumers. Even a small increase in the percentage of loyal consumers of the business is reflected in the high rate of business profitability (Özhan, 2015).

For this reason, it is important that the sports clubs and the enterprises that produce sports products to the supporters of the clubs understand the behaviours of the fans and accordingly determine their marketing strategies. This study was conducted to measure the evangelist attitudes of high school students, who are also club supporters and consumers, to sports teams and their products.

\section{Evangelism and Brand Evangelism}

Evangelism, which is associated with a religious meaning on its basis, has been used today to describe the passionate lover, the user and developer of an application, and the concept of brand evangelist has emerged. Evangelism was first used as 'Software Evangelist' in a non-religious sense in 1980 by Apple Marketing Manager, Guy Kawasaki. Kawasaki defined evangelism as "Evangelism is to make people believe in your product or ideas as much as possible. In other words, it means to sell your dreams with enthusiasm, effort, courage and love" (Kawasaki, 1991).

Brand evangelism, on the other hand, is defined as a passionate endeavour and a devotion to this endeavour in order to convince the people who are associated with a brand and to spread out the positive thoughts about it. It is possible to come across some concepts in literature review, such as "inspiring consumers", "brand devotees", "brand advocates" and "volunteer salespeople" that evoke the concept of brand evangelism (Matzler et all, 2007).

The brand evangelist makes the promotion of a brand voluntarily and actively without any financial expectations in order to positively influence the buying attitudes of others. Brand evangelists devote themselves to the brand beyond the passion or even beyond the mind (Roberts 2005). For such consumers, the products they use, the team they support, and the things that symbolize the team have very strong meanings. The consumer makes certain brands a part of his life and creates emotional bonds with this brand (Goldsmith, Flynn, Clark, 2011).

In literature review, some terms such as brand ambassador, a brand advocate, fan, supporter, affiliate fan are words closely used as brand evangelist. A brand advocate shares all the positive perceptions about a product and service, the positive aspects of the brand with other consumers, raises the awareness of products and services and encourages others to buy the products. Brand evangelists represent a level above brand advocacy in the position of the brand's missionaries. The messages that brand devotees and advocates try to spread about the brand are highly effective on indecisive customers for this brand (Balıkçığlu and Oflaz, 2015).

\section{Fanatics and Sports Team Evangelism (Efangelism)}

Supporting a sports team is an urban ritual, which is basically associated with the participation of the people who are passionate about their teams. Fanaticism, in terms of a football spectacle, includes some characteristics such as regarding all the legitimate ways to win, mainly considering the results, caring about the colours and anthem of the team with an irrational devotion etc. (Arikan, 2007). The most fundamental difference between fanatics and fans is that fanatics are more devoted to their team than fans are.

Today, the fanatical supporters, who transform this simple game into a national and international power, are the most important elements of football. A person who watches a sports activity directly or through the media is defined as a spectator, on the other hand, the person who devotes himself to his team, follows his team and its athletes, feels positive about them, supports them, is defined as a supporter (Arslanoğlu 2005). The person who is extremely passionate about his team is called fanatical (Koruç et all. 2004).

The fanaticism within the framework of a social approval in the sports expresses a sort of deadly love for a team and a great affinity to it (Kazan, 2009). The concept of sports fanaticism can be defined as the admiration and love for a person who performs in the sports activity, and for the team, branch or organization. It is a person who is extremely enthusiastic about and devoted to some interest or activity (Webster's Dictionary, 1976). At the same time a sports fan or fanatics is a consumer who is emotionally attached to sports and his team by a very extreme desire and passion. The fan admires sports and his team, and feels a commitment beyond his mind.

The concept of sports team evangelism was first used by Dwyer, Greenhalgh and LeCrom in 2015. While developing a 
scale about the concept, the word 'fan' which is the abbreviation of the word fanatic was placed within the word 'evangelism' and the word 'eFANgelism' emerged. The Sports Team Efangelism Scale (STES) measures the evangelist attitude of a sports team supporter individually for the sports team brand (Yüksekbilgili, 2017). In this context, the sports team 'efangelist' conveys his team, its products and services to his around with a non-materialist approach and without deviation, and he behaves as if he is a brand evangelist of his team with a sense of devotion.

In this study, the main aim is to determine the sports team evangelism (efangelism) attitudes of high school students and examine their evangelist behaviours.

\section{Methods}

This research aiming at examining the sports team evangelism (efangelism) attitudes of high school students is descriptive in the screening model. Screening models are research approaches that aim to describe a past or present condition as they are. The subject of the research, the individual or the object is tried to be defined in its own conditions and as it is (Karasar, 2005).

\section{Universe and Sample}

The universe of the research consists of the students studying at the high school in the central district of Sivas in the 2018/2019 academic year. The sample consists of the data selected and obtained from 376 student forms out of a total 400 ones after excluding the missing and/or mislabelled ones by the Convenience Sampling Method and then they are analysed.

\section{Data Collection Tool}

The 8-item personal information form prepared by the researcher was applied to determine the demographic characteristics of the participants. In addition, 12-item Sports Team Evangelism Scale developed by Dwyer, Greenhalgh and LeCrom (2015) and adapted to Turkish by Yüksekbilgili (2017) was used to determine the evangelistic (efangelistic) attitudes of the participants. The scale is evaluated as a one-dimensional scale.

\section{Data Analysis}

The data obtained from the study were analysed in the SPSS 22.0 statistical package program in accordance with the qualifications. Frequency, percentage, mean, standard deviation values were used in the classification of data. It was examined whether the data showed normal distribution before comparing the scale scores of the participants and non-parametric analyses were used because the scale data did not show normal distribution. Mann Whitney U test was used while comparing the scale scores in terms of participants' gender and the state of going to the away matches, Kruskal Wallis $\mathrm{H}$ test was used to compare the age scores, the class they attend in, the monthly income level of their families, the teams they support, their attendance frequency in the matches, and the means by which they follow the matches. 


\section{Findings}

Table 1. Frequency and Percentage Distributions related to Demographic Information of Participants

\begin{tabular}{|c|c|c|c|}
\hline Variables & Sub-variables & $\mathbf{f}$ & $\%$ \\
\hline \multirow{5}{*}{ Age Group } & 14 & 38 & 10,1 \\
\hline & 15 & 84 & 22,3 \\
\hline & 16 & 93 & 24,7 \\
\hline & 17 & 122 & 32,4 \\
\hline & 18 & 39 & 10,4 \\
\hline \multirow{3}{*}{ Gender } & Female & 209 & 55,6 \\
\hline & Male & 167 & 44,4 \\
\hline & $9^{\text {th }}$ & 104 & 27,7 \\
\hline \multirow{4}{*}{ Classroom } & $10^{\text {th }}$ & 56 & 14,9 \\
\hline & $11^{\text {th }}$ & 159 & 42,3 \\
\hline & $12^{\text {th }}$ & 57 & 15,2 \\
\hline & Low & 83 & 22,1 \\
\hline \multirow[t]{3}{*}{ Income level of the family } & Middle & 197 & 52,4 \\
\hline & High & 96 & 25,5 \\
\hline & Beşiktaş & 99 & 26,3 \\
\hline \multirow{2}{*}{ Supported Team } & Fenerbahçe & 102 & 27,1 \\
\hline & Galatasaray & 113 & 30,1 \\
\hline \multirow{6}{*}{$\begin{array}{c}\text { Frequency of Attendance in } \\
\text { Matches }\end{array}$} & Sivasspor & 62 & 16,5 \\
\hline & Every week & 99 & 26,3 \\
\hline & Once in a week & 35 & 9,3 \\
\hline & Once in a month & 49 & 13,0 \\
\hline & Fewer than 1 a month & 193 & 51,3 \\
\hline & Buying Combined Ticket & 30 & 8,0 \\
\hline \multirow{3}{*}{ The Forms of Follow-up } & Passolig Card & 46 & 12,2 \\
\hline & In Cafes & 61 & 16,2 \\
\hline & TV subscription & 239 & 63,6 \\
\hline \multirow{2}{*}{$\begin{array}{c}\text { The status of going to away } \\
\text { matches }\end{array}$} & Yes & 74 & 19,7 \\
\hline & No & 302 & 80,3 \\
\hline
\end{tabular}

When Table 1 is examined, $10.1 \%$ of the participants are 14 years old, $22.3 \%$ are 15 years old, $24.7 \%$ are 16 years old, $32.4 \%$ are 17 years old and $10.4 \%$ are 18 years old, and while $55.6 \%$ of the participants are women and $44.4 \%$ of them are men. $27,7 \%$ of the participants are 9th grade students, $14,9 \%$ are $10^{\text {th }}$ grade students, $42,3 \%$ are $11^{\text {th }}$ grade students and $15,2 \%$ are $12^{\text {th }}$ grade students. $22.1 \%$ of the participants stated that their families' monthly income level is low, $52.4 \%$ of them said that they have an intermediate level and $25.5 \%$ of them have a high level. $26.3 \%$ of the participants in the study are Beşiktaş fans, $27.1 \%$ are Fenerbahce fans, $30.1 \%$ are Galatasaray fans and $16.5 \%$ are Sivasspor fans. $26.3 \%$ of the participants go to a match every week, $9.3 \%$ go to a match once in 2 weeks, $13 \%$ go to a match once in a month and $51.3 \%$ go to a match fewer than once in a month. While $8 \%$ of the participants follow the matches by buying a combined ticket, $12.2 \%$ follow them by a Passolig card, $16.2 \%$ in cafes and $63.6 \%$ by means of their TV subscription. While $19.7 \%$ of the participants go to away matches, $80.3 \%$ do not go to away matches.

Table 2. Descriptive Statistics related to Evangelism Levels of Participants

$\begin{array}{ccccc}\mathbf{N} & \text { The Lowest } & \text { The Highest } & \mathbf{X} & \text { Ss } \\ 376 & 0 & 4 & 1,99 & , 977\end{array}$

When Table 2 is examined, it is determined that the average of evangelism levels of the individuals who participated in the study is $1.99 \pm 0.977$. 
Table 3. The Comparison of Evangelism Levels of Participants by Age Groups

\begin{tabular}{ccccccc}
\hline Age Group & $\mathbf{N}$ & $\mathbf{X}$ & Ss & Order avg. & $\mathbf{x}^{\mathbf{2}}$ & $\mathbf{p}$ \\
\hline $\mathbf{1 4}$ & 38 & 2,14 & 1,038 & 200,16 & & \\
$\mathbf{1 5}$ & 84 & 1,97 &, 860 & 186,37 & & \\
$\mathbf{1 6}$ & 93 & 1,88 & 1,020 & 174,82 & 2,484 &, 647 \\
$\mathbf{1 7}$ & 122 & 2,03 &, 983 & 195,06 & & \\
$\mathbf{1 8}$ & 39 & 2,03 & 1,050 & 193,85 & & \\
\hline
\end{tabular}

When Table 3 is examined, it is seen that sport team evangelism levels have not differed significantly in terms of age groups of the participants $(\mathrm{p}>0.05)$.

Table 4. Comparison of Evangelism Levels by Participants' Gender

\begin{tabular}{cccccccc}
\hline Gender & $\mathbf{N}$ & $\mathbf{X}$ & $\mathbf{S s}$ & Order avg. & $\begin{array}{c}\text { Total } \\
\text { Order }\end{array}$ & $\mathbf{U}$ & $\mathbf{p}$ \\
\hline Female & 209 & 1,76 &, 975 & 161,68 & 33790,5 & 11845,5 &, 000 \\
Male & 167 & 2,27 &, 907 & 222,07 & 37085,5 & \\
\hline
\end{tabular}

When Table 4 is examined, it is seen that the level of evangelism of participants according to the sports team they support significantly differ according to the gender group of the participants, and also the level of evangelism of the male participants is higher than the female participants' $(p<0.05)$.

Table 5. Comparison of Evangelism Levels of Participants by their Classes

\begin{tabular}{ccccccc}
\hline Class & $\mathbf{N}$ & $\mathbf{X}$ & Ss & Order avg. & $\mathbf{x}^{2}$ & $\mathbf{p}$ \\
\hline $\mathbf{9}$ & 104 & 1,98 &, 889 & 184,15 & & \\
$\mathbf{1 0}$ & 56 & 2,18 &, 981 & 209,54 & 6,770 &, 080 \\
$\mathbf{1 1}$ & 159 & 1,86 & 1,065 & 175,97 & & \\
$\mathbf{1 2}$ & 57 & 2,17 &, 819 & 210,72 & &
\end{tabular}

When Table 5 is examined, it is seen that sport team evangelism levels do not differ significantly according to the class levels of the participants ( $\mathrm{p}>0.05)$.

Table 6. Comparison of Evangelism Levels of Participants' Families by Monthly Average Income Level

\begin{tabular}{ccccccc}
\hline $\begin{array}{c}\text { The Level of } \\
\text { Income }\end{array}$ & $\mathbf{N}$ & $\mathbf{X}$ & Ss & Order avg. & $\mathbf{x}^{\mathbf{2}}$ & $\mathbf{p}$ \\
\hline Low & 83 & 1,88 &, 953 & 178,36 & & \\
Middle & 197 & 2,00 &, 978 & 188,22 & 1,437 &, 487 \\
High & 96 & 2,05 &, 998 & 197,85 & & \\
\hline
\end{tabular}

When Table 6 is examined, it is seen that the level of evangelism of the sports team is not statistically different according to the monthly income level of the families of the participants ( $>0.05)$.

Table 7. Comparison of Evangelism Levels according to the Teams of Participants

\begin{tabular}{cccccccc}
\hline Team & $\mathbf{N}$ & $\mathbf{X}$ & Ss & Order avg. & $\mathbf{x}^{2}$ & $\mathbf{p}$ & $\begin{array}{c}\text { Differences } \\
\text { in Groups }\end{array}$ \\
\hline Beşiktas & 99 & 1,94 & 1,069 & 181,97 & & & \\
Fenerbahce & 102 & 1,86 &, 936 & 171,56 & 10,042 &, 018 & $1<4,2<4$, \\
Galatasaray & 113 & 2,00 &, 869 & 189,20 & & & \\
Sivasspor & 62 & 2,27 & 1,040 & 225,52 & & & \\
\hline
\end{tabular}

When the Table 7 is examined, it is seen that the level of evangelism of the sports team is significantly different according to the teams they support, and the level of evangelism of the participants who are supporters of Sivasspor is higher than the other participants $(\mathrm{p}<0.05)$. 
Table 8. Comparison of Evangelism Levels according to the Participants' Frequency of Following a Match

\begin{tabular}{cccccccc}
\hline Frequency & $\mathbf{N}$ & $\mathbf{X}$ & Ss & $\begin{array}{c}\text { Order } \\
\text { avg. }\end{array}$ & $\mathbf{x}^{2}$ & $\mathbf{p}$ & $\begin{array}{c}\text { Differences } \\
\text { in Groups }\end{array}$ \\
\hline Every Week & 99 & 2,58 &, 838 & 255,22 & & & \\
Once in 2 weeks & 35 & 2,33 &, 862 & 226,56 & & & $1>3,1>4$, \\
$\begin{array}{c}\text { Once in a Month } \\
\text { Fewer than once a } \\
\text { month }\end{array}$ & 49 & 1,87 &, 861 & 173,30 & 65,310 &, 000 & $2>3,2>4$ \\
\hline
\end{tabular}

When Table 8 is examined, it is seen that sport team evangelism levels statistically differ significant according to the frequency of participants going to matches, and evangelism levels of the participants who go to the matches every week or once in 2 weeks are higher than the participants who go to the matches once in a month or fewer than once in a month $(\mathrm{p}<0.05)$.

Table 9. The Comparison of Evangelism Levels according to the Forms of Participants' Follow-Up Methods

\begin{tabular}{cccccccc}
\hline Forms of Follow-up & $\mathbf{N}$ & $\mathbf{X}$ & $\mathbf{S s}$ & $\begin{array}{c}\text { Order } \\
\text { avg. }\end{array}$ & $\mathbf{x}^{\mathbf{2}}$ & $\mathbf{p}$ & $\begin{array}{c}\text { Differences } \\
\text { in Groups }\end{array}$ \\
\hline $\begin{array}{c}\text { Buying Combined } \\
\text { Tickets }\end{array}$ & 30 & 2,46 &, 945 & 239,92 & & & \\
Passolig Cards & 46 & 2,31 & 1,017 & 222,15 & 20,003 &, 000 & $1>4,2>4,3>4$ \\
$\quad$ In Cafes & 61 & 2,16 &, 926 & 209,03 & & & \\
TV Subscription & 239 & 1,83 &, 949 & 170,33 & & & \\
\hline
\end{tabular}

When Table 9 is examined, it is seen that statistically sport team evangelism levels differ significantly according to the way participants follow matches, and evangelism levels of the participants who buy the combined tickets, buying the Passolig cards or following the matches in the cafes are higher than the ones following the matches by means of the TV subscription $(\mathrm{p}<0,05)$.

Table 10. The Comparison of Evangelism Levels according to the Status of the Participants' Going to the Away Matches of Their Team

\begin{tabular}{cccccccc}
\hline $\begin{array}{c}\text { Status of } \\
\text { Going } \\
\text { Away } \\
\text { Matches }\end{array}$ & N & X & Ss & Order avg. & $\begin{array}{c}\text { Total } \\
\text { Order }\end{array}$ & U & p \\
\hline Yes & 74 & 2,34 & 1,007 & 226,86 & 16788,0 & 8335,0 &, 001 \\
No & 302 & 1,90 &, 951 & 179,10 & 54088,0 & & \\
\hline
\end{tabular}

When Table 10 is examined, it is seen that the level of evangelism of sport team they are supporting is differentiated according to the status of their following of the teams in away matches, and that the level of evangelism of the participants going to the away matches is higher than the participants who did not go to the away matches $(\mathrm{p}<0,05)$.

\section{Discussion and Conclusion}

It is very important for the incorporated clubs to know what the consumption behaviours of their supporters and fans are, however it is very difficult to predict what these behaviours are. Team supporters or efangelists who are voluntarily formed are brand advocates for their incorporated clubs, they are people who are irrationally deeply connected to their teams, who promote the products of their teams, or they are even team members who work like salespersons and who act as advertising staffs, therefore they are very important for clubs. Because the advertisement, promotion and advocacy of the services and products offered by the clubs are made voluntarily and actively by those efangelists. In a sense, the club markets its products and services through its own promoters, efangelists, without any cost to the club in its competitive environment. In this context, the sports team efangelism is important for clubs having both fans and consumers, as well.

When the evangelist attitudes of the sports team supporters for the products and services of the sports team are individually examined, it is seen that the sports team evangelism levels of the participants are moderate. It is seen that the sports team evangelism levels differ significantly according to the gender of the participants, their frequencies of attendance in away matches, the frequencies of going to the matches, the means by which they follow the matches. 
According to the gender, it is found that the level of evangelism of the sports team of the male participants is higher than that of the female participants. In their study, Altınok and et all. (2017) examined the level of identification of high school students who support their team, and they founded that there is a significant difference between the male and female students' identification levels. In the test results, it is stated that the identification scores of the sports supporters as the male students are higher than the female students' identification scores. The result obtained is in parallel with the results of the study.

It is found in this study that according to the team groups, Sivasspor supporters' sports team evangelism level is higher than other team supporters, and according to the frequency of going to the matches, the ones who go to the matches every week or twice a week have higher evangelism levels than the ones who go to the matches once a month or fewer than once a month. The result shows that the local tendencies of people emerge and they feel themselves as if they belong to the sports teams of the city they live in. On the other hand, it is possible to think that they have better access to the team they closely follow.

In terms of the follow-up ways, it is found that the level of evangelism of the participants who have passolig cards or following the matches in the cafes are higher than the participants who follow the matches by means of their TV subscriptions, and it is also found that in terms of the status of the fans' going to the away matches, their level of evangelism is higher than the participants who do not go to the away matches. It is found that the individuals with high levels of evangelism have tendencies to follow the matches with the other fans they share the same team with. It is said that individuals with high levels of sport evangelism are also more inclined to support their teams, and they tend to devote more time to their teams.

There is no difference in their level of evangelism considering the participants' variables in terms of their age, gender groups, education level, classrooms and family income.

Sport team evangelism scale is quite new in the literature review. The study covers only high school students in the province of Sivas in Turkey. Studying the subject matter in terms of different variables in different regions of the world will contribute to the literature review. The research is important for the analysis of the consumer profile for incorporated teams and other businesses that offer sports products and services. For this reason, it is important for the sports clubs and the enterprises that produce sports products for the supporters of these clubs to understand the behaviours of the fans, and to determine their marketing strategies accordingly.

In the light of the results of this research in which the evangelist attitudes towards sports teams and sports products are measured in the age group at the high school level, the enterprises can review the consumer profiles.

\section{References}

Alkibay, S. (2005). A Research on Professional Sport Clubs' Creation of Brand Values through Fan Relations. Journal of Hacettepe University Faculty of Economics and Administrative Sciences, 23(1), 83-108.

Altınok, B., Ekinci, N., Çimen, K., Özdilek, Ç., \& Kaya, İ. (2017). Investigation of Identity Levels of High School Students. Journal of Sport Education, 1 (1), 59-68.

Amine, A. (1998). Consumers' True Brand Loyalty: The Central Role of Commitment. Journal of Strategic Marketing 6, 4, 305-319. https://doi.org/10.1080/096525498346577

Arıkan, Y., \& Çelik, O. (2007). Violence in Football and Police. Journal of Police Sciences, 9(1), 109-192.

Arslanoğlu, K., \& Özkan, K. (2005). Psychiatry of Football: Psychology and Psychiatry of Sport. İthaki Publications, İstanbul.

Balıkçıŏlu, B., \& Oflazoğlu, S. (2015) An Empirical Research on Brand Evangelism, Self-Brand Image Alignment and Brand Loyalty.

Dwyer, B., Greenhalgh, G. P., \& Lecrom, C. W. (2015). Exploring Fan Behavior: Developing a Scale to Measure Sport Efangelism, Journal Of Sport Management, 29(6), 642-656. https://doi.org/10.1123/JSM.2014-0201

Goldsmith, R. E., Flynn, L. R., \& Clark, R. A. (2011). Materialism and brand engagement as shopping motivations. Journal of Retailing and Consumer Services, 18(4), 278-284.

https://doi.org/10.1016/j.jretconser.2011.02.001

Karasar, N. (2005). Scientific research method (17th edition). Ankara: Nobel Publishing, 81-83.

Kawasaki, Guy (1991). Selling the Dream, New York, NY: Harper Collins Publishers.

Kazan, B. (2009). Football Fanaticism and Violence in Turkey, Mimar Sinan Fine Arts University, Institute of Social Sciences, M.Sc., 103, İstanbul. 
Koruç, Z., Bayar, P., \& Arslan, F. (2004). Football fanatic in Turkey: Social Identity and Violence. Man Football Association of Turkey Ankara Branch and the Directorate General of Sports Toto terror Football Competition Causes and Prevention Ways Scientific Research Competition. Ankara.

Matzler, K., Pichler, E. A., \& Hemetsberger, A. (2007). Who is Spreading the Word? The Positive İnfluence of Extraversion on Consumer Passion and Brand Evangelism. Marketing Theory and Applications, 18(1), 25-32.

Özhan, Ş. (2015). An Empirical Research on Personality Traits and Nostalgia Tendency on Brand Loyalty., Trakya University, Institute of Social Sciences, Department of Business Administration, PhD Thesis, 51, Edirne

Roberts, K. (2005). Lovemarks: The future beyond brands. Powerhouse books.

Solomon, M. R. (2013). Consumer Behaviour: Buying, Having, And Being, 10th Ed., Upper Saddle River, NJ: Pearson Education.

Webster Dictionary (1976). The English Language İnstitue of America İnc.

Yüksekbilgili, Z. (2017). Adaptation of Turkish Sports Team Evangelism (eFANgelism) Scale to Turkish: Reliability and Validity Study. Management and Economics: Celal Bayar University Journal of the Faculty of Economics and Administrative Sciences, 24(3), 959-969.

\section{Copyrights}

Copyright for this article is retained by the author(s), with first publication rights granted to the journal.

This is an open-access article distributed under the terms and conditions of the Creative Commons Attribution license which permits unrestricted use, distribution, and reproduction in any medium, provided the original work is properly cited. 